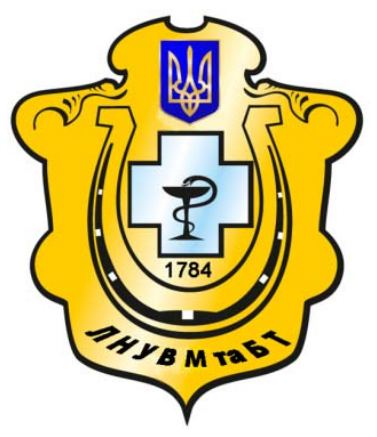

Науковий вісник Львівського національного університету ветеринарної медицини та біотехнологій імені С.З. Гжицького

Scientific Messenger of Lviv National University of Veterinary Medicine and Biotechnologies named after S.Z. Gzhytskyj

doi:10.15421/nvlvet7607

ISSN 2519-2701 print

ISSN 2518-1327 online

http://nvlvet.com.ua/

УДК 332.3:631.95

\title{
Перспективи аграрної галузі в контексті інтеграційних процесів з СС
}

\author{
Р.С. Грабовський ${ }^{1}$, О.О. Дадак ${ }^{1}$, Ю.М. Музичка ${ }^{1}$, Р.П. Дудяк ${ }^{2}$ \\ romansg@ukr.net \\ ${ }^{I}$ Львівський національний університет ветеринарної медицини та біотехнологій імені С.3. Гюсицького, \\ вул. Пекарська, 50, м. Львів, 79010, Украӥна; \\ ${ }^{2}$ Львівський національний аграрний університет, \\ вул. Володимира Великого, 1, Дубляни, Львівська обл., 80381, Украӥна
}

\begin{abstract}
У статті проаналізовано перспективи нарощування експорту вітчизняної продукиї аграрного сектора в країни Свропейського Союзу та можливості розширення збуту вітчизняної аграрної продукиії на цьому ринку. Особливість співпраці між Україною і країнами СС полягає у скасуванні більшості мит на експорт продукиії, запровадженням тарифного квотування. Для успішного розв'язання завдань євроінтеграчії аграрний сектор економіки Украӥни має достатньо передумов: багатий природно-ресурсний та експортний потенціал, вагомий людський капітал, поступово зростаючу інвестиційну привабливість, збережений уклад сільського життя та багатовікові традииї ведення сільського господарства. У публікації подано алгоритм дій, який дає можливість налагодити співпрацю із іноземними партнерами та вказано напрями підвищення ефективності аграрного виробництва. Наведено основні групи продовольчих товарів, 3 якими конкуруватиме вітчизняна продукиії на внутрішньому $і$ зовнішньому ринках у результаті спрощення умов для товарообороту між Украӥною і крайнами Свропейського Союзу. Основними вітчизняними експортними продуктами є зерно, насіння соняшника, олія, корми для тварин, добрива. В статті описано умови, які необхідно виконувати для реалізації продукиії на експорт в СС. Завдяки гарантуванню якості та безпеки нашої продукції на рівні європейських стандартів вітчизняний сільськогосподарський виробник зможе ефективно конкурувати на ринку Європейського Союзу. Оскільки доступ на ринок Свропейського Союзу може бути отриманий після проходження процедур сертифікації та отримання відповідних дозволів.
\end{abstract}

Ключові слова: ринок, сільськогосподарська продукиія, Свропейський Союз, конкурентоспроможність, експорт, макросередовище, чинники, сертифікація, квоти.

\section{Перспективы аграрной отрасли в контексте интеграционных процессов с ЕС}

\author{
Р.С. Грабовскийํㅡㄹ О.О. Дадак ${ }^{1}$, Ю.М. Музычка ${ }^{1}$, Р.П. Дудяк ${ }^{2}$ \\ romansg@ukr.net
}

\footnotetext{
${ }^{1}$ Львовский нащиональный университет ветеринарной медищины и биотехнологий имени С.3. Гжицкого, ул. Пекарская, 50, г. Львов, 79010, Украина;

2 Львовский наииональный аграрный университет, ул. Владимира Великого, 1, г. Дубляны, Львовская обл., 80381, Украина
}

В статье проанализированы перспективы наращивания экспорта отечественной продукиии аграрного сектора в страны Европейского Союза и возможности расширения сбыта отечественной аграрной продукиии на этом рынке. Особенность сотрудничества между Украиной и странами ЕС заключается в отмене большинства пошлин на экспорт продукиии, внедрением тарифного квотирования. Для успешного решения задач евроинтеграции аграрный сектор Украины имеет достаточно предпосылок: богатый природно-ресурсный и экспортный потенциал, весомый человеческий капитал, постепенно растушую инвестиционную привлекательность, сохранен уклад сельской жизни и многовековые традиции ведения

\section{Citation:}

Grabovskyi, R.S., Dadak, O.O., Muzychka, Y.M., Dudyak, R.P. (2017). Perspectives in the agricultural sector integration with the EU. Scientific Messenger LNUVMBT named after S.Z. Gzhytskyj, 19(76), 35-38. 
сельского хозяйства. В публикацчи представлен алгоритм действий, позволяюший наладить сотрудничество с иностранныли партнерами и указаны направления повышения эффективности аграрного производства. Приведень основные группы продовольственных товаров с которыми будет конкурировать отечественная продукции на внутреннем и внешнем рынках в результате упрощения условий для товарооборота между Украиной и странами Европейского Союза. Основньми отечественными экспортными продуктами являются зерно, семена подсолнечника, масло, корма для животных, удобрения. В статье описаны условия, которые необходимо выполнять для реализации продукции на экспорт в ЕС. Благодаря обеспечения качества и безопасности нашей продукиии на уровне европейских стандартов отечественный сельскохозяйственный производитель сможет эффективно конкурировать на рынке Европейского Союза. Поскольку доступ на рынок Европейского Союза может быть получен после прохождения процедур сертификации и получения соответствующих разрешений.

Ключевые слова: рынок, сельскохозяйственная продукция, Европейский Союз, конкурентоспособность, экспорт, макросреда, факторы, сертификачия, квотьл

\title{
Perspectives in the agricultural sector integration with the EU
}

\author{
R.S. Grabovskyi ${ }^{1}$, O.O. Dadak ${ }^{1}$, Y.M. Muzychka ${ }^{1}$, R.P. Dudyak ${ }^{2}$ \\ romansg@ukr.net \\ ${ }^{1}$ Lviv National University of Veterinary Medicine and Biotechnologies named after S.Z. Gzhytskyi, \\ Pekarska Str., 50, Lviv, 79010, Ukraine; \\ ${ }^{2}$ Lviv National Agrarian University, \\ Volodymyr Velykyi Str., 1, Dubliany, Lviv, 80381, Ukraine
}

The article analyzes the prospects for increased exports of domestic products of the agricultural sector in the European Union and the possibility of expanding the domestic marketing of agricultural products in the market. Feature of cooperation between Ukraine and the EU is the abolition of duties on most exports, the introduction of tariff quotas. The successful solution of problems of European integration agrarian sector of Ukraine has enough prerequisites: rich in natural resources and export potential, significant human capital, gradually increasing the investment attractiveness saved the rural way of life and old traditions of farming. The publication presents an algorithm of actions, which makes it possible to establish cooperation with foreign partners and specified areas of improving the efficiency of agricultural production. The basic groups of food products that compete with domestic products in domestic and foreign markets as a result of simplifying the conditions for trade between Ukraine and the European Union. The main domestic export products are corn, sunflower seed oil, animal feed, fertilizer. is corn, sunflower seed oil, animal feed, fertilizer. The article describes the conditions that must be met for the sale of products for export to the EU. Owing to ensure quality and safety of our products to European standards for domestic agricultural producers will be able to effectively compete in the market of the European Union. As access to the market of the European Union can be obtained after passing certification procedures and obtaining appropriate permits.

Key words: market agricultural products, the European Union, competitiveness, exports, macro factors, certification, quotas

\section{Вступ}

Актуальність теми. Сучасний стан сільськогосподарського ринку перебуває під впливом низки макрорівневих чинників, які мають на нього визначальний вплив. У цій статті зосередимо свою увагу на одному з таких чинників, який має стимулюючий вплив на розвиток вітчизняного аграрного виробництва, а саме спрощення доступу вітчизняної продукції на ринок Європейського Союзу. Розширення можливостей експорту вітчизняної продукції на ринок ЄС сприятиме підвищенню якісних показників аграрної продукції, зростанню інвестицій в аграрну сферу, зумовить створення нових робочих місць в галузі, поліпшить соціально-економічну ситуація в селі тощо.

Мета $і$ завдання дослідження Основною метою дослідження $є$ аналіз перспектив доступу вітчизняного виробника на ринок ЄС. Для досягнення цієї мети потрібно оцінити позитивні сторони економічної інтеграції з ЄС, бар'єри, що гальмують просування вітчизняної продукції на цей ринок та загрози для вітчизняного виробника.

Аналіз останніх досліджень $і$ публікацій. Значну увагу дослідженню проблематики та перспектив експорту вітчизняної аграрної продукції на ринок Свро- пейського Союзу приділено в наукових публікаціях вчених Ю.Е. Губені, Б.Г. Базилюка, В. Сіденка, О. Лошкарьова, I. Бережнюка, С. Боротничека, А.С Гальчинського, О.А. Корнієвського та ін. Слід зазначити, що обговорення економічних вигод і загроз від такої співпраці на фоні економічної і політичної ситуації, яка динамічно міняється, не втрачає свої актуальності.

\section{Результати та їх обговорення}

Аграрний сектор України вже більш ніж два десятиліття, перебуваючи під впливом низки економічних та політичних чинників, не використовує свою потенціалу повністю. Розглядаючи перспективи інтеграції України в економічне і політичне середовище ЄС потрібно оцінити можливості розширення збуту вітчизняної аграрної продукції на цьому ємнісному ринку. Як зміняться умови для експортно-імпортних операції між Україною і $Є С$, чи зможе вітчизняний виробник запропонувати на ринку СС продукцію, яка відповідає його вимогам.

Станом на сьогодні сільське господарство продовжує залишатися експортною галуззю №1 в Україні. Загалом, АПК забезпечує 14\% загального обсягу ВВП країни. Так, наприклад, за 7 місяців 2015 року аграр- 
ному сектору вдалося забезпечити обсяг експорту продукції на рівні 7,7 млрд доларів, що становить 35\% валютних надходжень від експорту всіх товарів. Але важливо інше: Україні необхідно відійти від практики сировинного експорту в бік поставок готової продукції 3 додатковою вартістю (Rozvytok agrarnogo sektoru..., 2015).

Особливість співпраці між Україною і країнами ЄС полягає у скасуванні більшості мит на експорт продукції, запровадженні тарифного квотування. Таким чином, стратегічним завданням для вітчизняного виробника $\epsilon$ адаптація технологічних процесів до випуску продукції, що відповідатиме стандартам безпеки і якості в СС. Перспективи росту експорту в СС агропродукції залежать від успішної уніфікації стандартів, вимог та системи контролю за продукцією. Підприємства повинні інвестувати в модернізацію виробництва.

Основними вітчизняними експортними продуктами $є$ зерно, насіння соняшнику, олія, корми для тварин, добрива. На перелічену продукцію вже діють нульові ставки експортного мита. Вигідним для Українського сільськогосподарського виробника $є$ 10-річний перехідний період скасування українських торгівельних мит. Це дасть можливість поступово відкривати вітчизняний продовольчий ринок для висококонкурентної за якістю і ціною європейської продукції.

Позитивною стороною посилення торгівлі між Україною та ЄС є також ріст інвестиційних потоків в аграрну сферу. Для успішного розв'язання завдань євроінтеграції аграрний сектор економіки України має достатньо передумов: багатий природноресурсний та експортний потенціал, вагомий людський капітал, поступово зростаючу інвестиційну привабливість, збережений уклад сільського життя та багатовікові традиції ведення сільського господарства. У цьому контексті дослідження та наукове осмислення досвіду формування європейської аграрної моделі сприятимуть проведенню структурних реформ у галузі сільського господарства та підвищенню рівня конкурентоспроможності агропродовольчої продукції на європейському та світовому ринках.

Відсутність досвіду експорту в ЄС для багатьох українських виробників вимагає використання чіткого алгоритму дій, який дає можливість налагодити співпрацю із іноземними партнерами. Насамперед потрібно провести маркетингове дослідження попиту на продукцію, кон'юнктуру ринку. Наступний етап - це чітке визначення бізнес-партнера, партнерів, що згідні закуповувати продукцію підприємства. Далі менеджер вивчає документацію, пов'язану 3 експортом продукції, наявність квот та ставки мита. Залежно від характеристики продукції підприємець отримує дозволи і здійснює експортну операцію. Саме цей алгоритм дій $є$ таким, що забезпечить успішний експорт. В контексті розвитку експортної діяльності підприємства та пошуку партнерів також можна брати участь у відповідних виставках та ярмарках.

Зростання експорту продукції вітчизняного аграрного сектора може вирішити низку екологічних проблем українського НПС. Екологізація аграрного ви- робництва зумовлює підвищення якісних показників продукції і ріст експорту, ріст експорту впливає на удосконалення виробництва продукції, використання ресурсоощадних технологій (Grabovsky ana Dudjak, 2013).

Ріст експортно-імпортних операцій зумовлює загострення конкуренції на ринку. Найбільше українська агропродовольча продукція конкуруватиме 3 такими товарними групами європейських товарів, як: тварини в живій вазі, готові чи консервовані продукти 3 м'яса, готові чи консервовані продукти з риби; живі рослини та продукти квітництва; овочі, рослини та коренеплоди; кава, чай, мате та прянощі; насіння та плоди для сівби; какао-боби і продукти з них тощо.

Найбільш значущими українськими агропродовольчими товарами на ринках ЄС будуть: кукурудза; насіння олійних культур; матеріали рослинного походження; олія; цукор, меляса, кондвироби; пшениця та суміш пшениці й жита (меслин); мед; залишки і відходи харчової промисловості. Саме ці продукти, маючи конкурентні переваги, визначатимуть реальні експортні обсяги українських товарів до СС (Pugachov, 2016). За рахунок виходу на ринок ЄС український виробник зможе наростити виробництво продукції, гарантувати збут, удосконалити технологію. Для прикладу, низька платоспроможність населення України стримує розвиток виробництва органічної продукції, яку можна реалізувати на зовнішньому ринку (Grabovsky and Djak, 2012).

Одним 3 магістральних напрямів підвищення ефективності аграрного виробництва і найперспективнішою сферою залучення іноземних інвестицій $є$ розвиток переробних галузей промисловості. Переробка сільськогосподарської сировини забезпечує втричі вищу прибутковість, ніж іiі виробництво. Тому, 3 огляду на привабливість цієї сфери для вкладання інвестицій, на недорозвиненість переробної промисловості в Україні, а також на перспективний внутрішній ринок для якісних продуктів харчування вітчизняного виробництва, переробна сфера АПК повинна стати пріоритетним напрямом його розвитку (Kunyc'ka-Iljash, 2011). Важливим завданням державного рівня $є$ удосконалення вітчизняного законодавства в напрямку наближення до фітосанітарних норм ЄC. Лише у разі гарантування якості та безпеки нашої продукції на рівні європейських стандартів ми зможемо ефективно конкурувати на ринку СС. Недотримання стандартів ЄС зумовлює недовикористання тарифних квот на експорт української продукції. Деякі групи квот потребують від українських виробників проходження процедур сертифікації та отримання відповідних дозволів. Наприклад, у 2016 році було вперше частково використано квоти на вершкове масло (46\%) та сухе молоко (30\%). На сьогодні право експорту своєї продукції на територію Свропейського Союзу мають 266 українських підприємств. 3 них 86 підприємств - виробники продукції для кінцевого споживання, 180 підприємств - виробники нехарчової продукції. Багато квот не використовуються українськими експортерами (гриби, часник, яловичина, баранина, свинина, продукти з обробленого молока, крохмаль та багато інших позицій). Насамперед, щоб наша 
аграрна продукція відповідала європейським стандартам безпеки та якості. Наприклад, для здійснення експорту яловичини до ЄС в Україні на національному рівні має бути введена в дію система моніторингу на захворювання губчастоподібною енцефалопатією великої рогатої худоби. Україна поки що не використовує безмитні квоти на часник, але розвиток цього напрямку матиме успіх для малих та середніх виробників. Так, ця культура складна в обробітку, але ретельне напрацювання технологій обробки в результаті забезпечить добрі досягнення в цій галузі. Наразі встановлення безмитних тарифних квот СС передбачено для 36 видів товарів (яловичина, свинина, м'ясо баранини, м'ясо птиці, молоко, вершки, йогурти, зернові, висівки, мед, цукор, крохмаль, гриби, часник, солод, виноградний і яблучний соки, вершкове масло, цигарки, етанол, яйця та альбуміни тощо). Інформація про поточні залишки тарифних квот, які управляються на основі принципу «перший прийшов - перший обслуговується», доступна в режимі он-лайн у відповідному розділі на офіційному порталі Свропейської Комісії. Водночас імпорт товарів понад визначений обсяг підпадатиме під загальний режим імпорту, тобто оподатковуватиметься за тими ж умовами, які діяли для України до запровадження вільної торгівлі.

Важливо, щоб виробники були зацікавлені у розвитку хоча б первинної переробки та були здатні кооперуватися між собою у взаємодоповнюючі кластери. Це значно примножить сили малих фермерів для подолання міжнародної конкуренції (Trofimceva, 2016).

\section{Висновки}

Дослідження дозволяє зробити висновок про важливість адаптації українського виробника до стандартів продовольчого ринку країн СС. Саме за рахунок підвищення якісних показників вітчизняної продукції можливо використати шанси зростання прибутку за рахунок збуту своєї продукції на ринку СС. Незначна ємність вітчизняного ринку є стримуючим фактором для нарощення виробництва продукції вітчизняними аграрними виробниками.
Перспективи подальших досліджень. Дослідження проблематики розширення ринків збуту $є$ однією із найважливіших завдань для вітчизняної науки. У цьому контексті важливо проводити аналіз шляхів підвищення конкурентоспроможності вітчизняної продукції на зовнішніх ринках, удосконалення виробництва, підвищення прибутковості.

\section{Бібліографічні посилання}

Rozvytok agrarnogo sektoru - perspektyvne majbutnje Ukrai'ny? (2015). [Elektronnyj resurs]. Rezhym dostupu: http://www.slovoidilo.ua/2015/09/22/stattja/ ekonomika/rozvytok-ahrarnoho-sektoru-perspektyvnemajbutnye-ukrayiny (in Ukrainian).

Grabovsky, R.S., Dudjak, R.P. (2013). Suchasnyj stan ta perspektyvy ekologizacii' agrovyrobnyctva v Ukrai'ni. Naukovyj visnyk NLTU Ukrai'ny. 23(2), 135-141 (in Ukrainian).

Pugachov, M. (2016). Eksport ukrai'ns'koi' sil's'kogospodars'koi' prodovol'choi' produkcii' do JeS zroste do 4,7 mlrd dol. - prognoz. [Elektronnyj resurs]. Rezhym dostupu: http://www.agrobusiness.com.ua/agrobusiness/events/4652-2016eksport-ukraiinskoii-silskogospodarskoiiprodovolchoii-produktsiii-do-ies-zroste-do-47-mlrddol-prognoz.html (in Ukrainian).

Grabovsky, R.S., Djak, O.T. (2012). Organichne vyrobnyctvo jak sposib ekologizacii' agrarnoi' sfery Naukovyj visnyk LNUVMBT imeni C.Z.G'zhyc'kogo. 14, 1(51), 169-172 (in Ukrainian).

Kunyc'ka-Iljash, M.V. (2011). Jevropejs'kyj dosvid derzhavnogo reguljuvannja ta pidtrymky rozvytku agrarnogo sektoru ekonomiky ta mozhlyvosti jogo zastosuvannja v Ukrai'ni. Naukovyj visnyk LNUVMBT imeni C.Z. G'zhyc'kogo. 13, 4(50), 135144 (in Ukrainian).

Trofimceva, O. (2016). Kvoty i ne til'ky: de Ukrai'na mozhe narostyty eksport do JeS. [Elektronnyj resurs]. Rezhym dostupu: http:/www.eurointegrati on.com.ua/ experts/2016/11/8/7057104/ (in Ukrainian).

Стаття надійшла до редакції 13.03.2017 